\title{
The impact of Psittacula krameri (Scopoli, 1769) on orchards: first quantitative evidence for Southern Europe
}

\author{
Lorenzo Mentil ${ }^{1}$, Corrado Battisti ${ }^{2, *}$ \& Giuseppe M. Carpaneto ${ }^{1}$ \\ ${ }^{1}$ Dipartimento di Scienze, Università Roma Tre, viale Marconi, 446, 00146 Rome, Italy \\ 2'Torre Flavia' LTER (Long Term Ecological Research) Station, Protected areas - Regional park, \\ Service, Città Metropolitana di Roma Capitale, via Tiburtina, 691, 00159 Rome, Italy. \\ ${ }^{*}$ Corresponding author: c.battisti@cittametropolitanaroma.gov.it
}

KEYWORDS. Non-native species, pest, Prunus dulcis, economic damage, Italy.

Mentil L., Battisti C. \& Carpaneto G.M. (2018). The impact of Psittacula krameri (Scopoli, 1769) on orchards: first quantitative evidence for Southern Europe. Belgian Journal of Zoology 148 (2): 129-134. https://doi.org/10.26496/bjz.2018.22

Birds often cause severe damage to agricultural crops, particularly at the harvest stage [1-3]. In this regard, the assessment of their crop damage is the key to developing methods to reduce such damage and to delineate management policies [4-5].

Among non-native species, the ring-necked parakeet Psittacula krameri (Scopoli, 1769), with an afro-indian distribution, has invaded several areas of Europe in recent decades, and ranks among the world's most successful introduced birds [6]. Although the species has long been considered a potential economic threat to agriculture (depredation on fruits, feeding on orchard fruits, maize and oil-seed crops [7-9]), damage to crops has been largely evaluated in countries where this species is native [e.g., 8, 10-13]. Nevertheless, although data on diet are locally available [e.g., 14-15], excluding occasional reports [16-18], quantitative data on the specific impact on orchards are still scanty in Europe and entirely lacking for Southern Europe.

In this note we report the evidence for an impact of ring-necked parakeet on a suburban almond orchard inside the metropolitan area of Rome that holds one of the largest densities of ring-necked parakeet in Europe [19-22].

The study was conducted in the South East section of the "Appia Antica" regional park (1600 ha-wide), within the experimental fields of the CREA-OFA Research Center (between $41^{\circ} 48^{\prime} 04.7^{\prime \prime} \mathrm{N} / 12^{\circ} 33^{\prime} 54.9^{\prime \prime} \mathrm{E}$ and $41^{\circ} 47^{\prime} 13.2^{\prime \prime} \mathrm{N} / 12^{\circ} 34^{\prime} 10.3^{\prime \prime} \mathrm{E} ; 50 \mathrm{~m}$ a.s.l., Rome, central Italy). In the surrounding landscape there are patches of Mediterranean forests with Holm Oak (Quercus ilex) and Downy Oak (Quercus pubescens) and residual disturbed woods of Turkey Oak (Quercus cerris) connected with hedgerows in a predominantly agricultural matrix. Riparian forests, dominated by the White Willow (Salix alba) with scarcity of undergrowth, and riparian reed beds dominated by Giant Reed (Arundo donax) are also present [19-20]. The total area occupied by the Research Center is about 66 hectares, all contiguous. The experimental field consists of about 6000 varieties of fruit species grown in Italy (mainly Prunus 
armeniaca, P. dulcis, P. avium, P. persica, P. domestica, Actinidia chinensis, Malus domestic, Pyrus communis).

We focused our quantitative survey only on the almond orchard (Prunus dulcis). The cultivated area occupied by this type of orchard was a rectangular patch of 0.8 hectares in total (about 100 in length $\times 80 \mathrm{~m}$ in breadth; $\mathrm{n}=452$ trees) within a wider field of about 2 ha including mixed cultivations of other species. This field is used specifically for experimental organic farming (only treatments with total absence of pesticides). The physical structure of almond trees is relatively homogeneous with plants having a trunk average diameter (at chest height) of $26( \pm 5.47) \mathrm{cm}$, by about 2.5 meters in height (age: 15 years).

The study was carried out in September 2017 when the almond fruits are ripe, and furthermore it is the end of the breeding period of ring-necked parakeets so that juveniles may also forage on fruits [23]. A previous census using point count method $(n=120$; sessions with fixed time: 5 min.) in all experimental orchards estimated a number ranging between 0-3 ind./session (G. Assogna, unpublished data). To obtain data on the impact of parakeets on almond fruits, first we randomly selected a set of trees $(n=48)$ inside the almond orchard sample, using a random number generator. Then, we counted the number of total available almond fruits occurring on each tree, checking for the almond fruits with evident damage caused by ring-necked parakeet (about four hours in the sampling effort in a single sampling day). All the fruits that showed evident damage from scarification and rupture (as shown in Fig. 1) were counted. We assigned the damage on almonds to the specific action of parakeets, considering

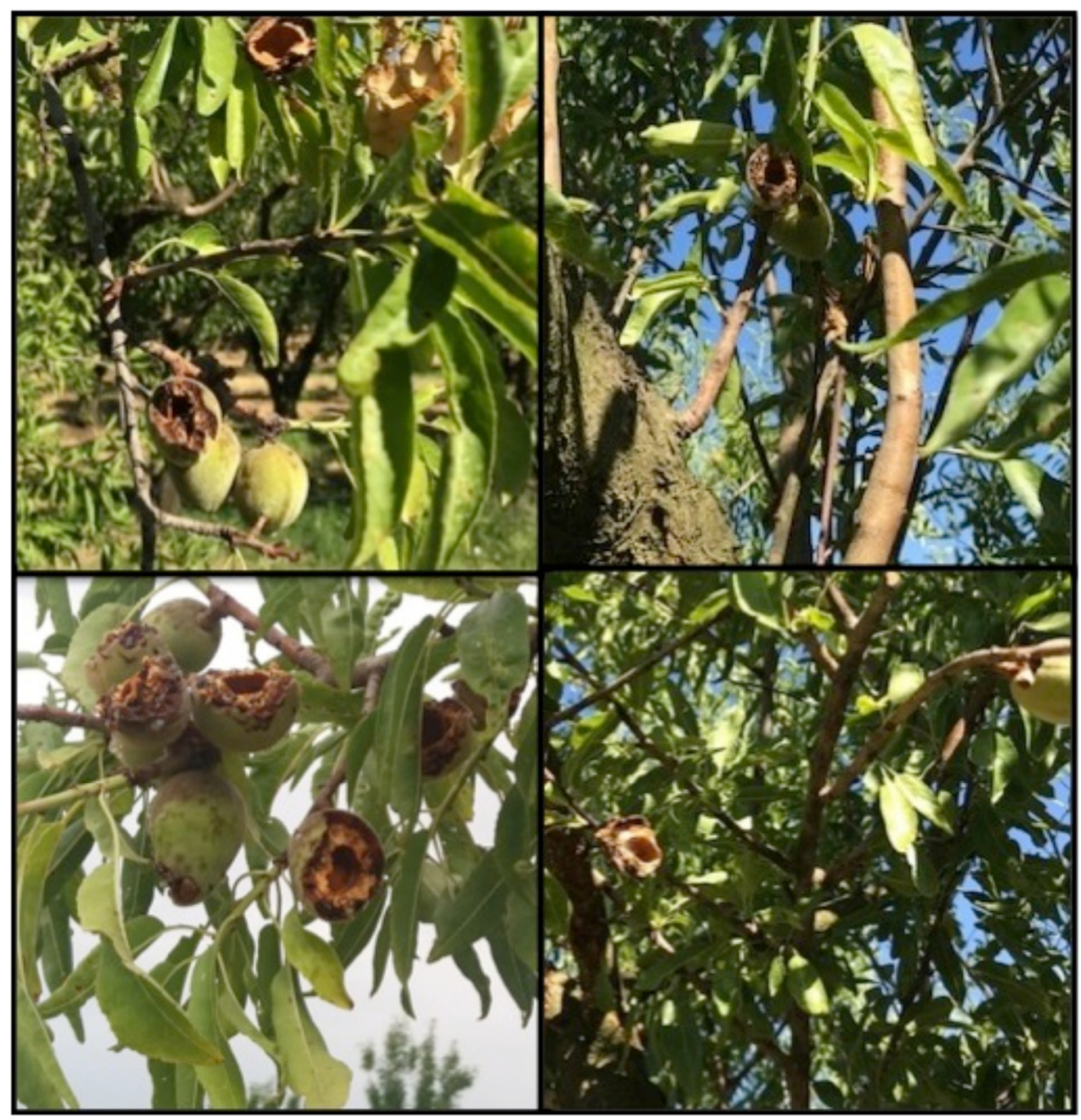

Fig. 1 - Fruit damage caused by ring-necked parakeet, Psittacula krameri, on almonds (Rome, central Italy; for quantitative data, see results). 
that they completely break the fruit (individuals eat the almond fruits by breaking the exocarp and the mesocarp, thus extracting the seed contained within the endocarp, the inedible fleshy part; [12]).

From field data, we obtained: (i) the frequency (for each tree and for the total; $n=48$ trees) of almonds damaged out of the total of almond records, (ii) the mean number of available almonds/tree and damaged almonds/tree. We compared the frequencies using a $\chi^{2}$ test; we correlated variables (almond vs. damaged almonds, and tree distance from edge vs. percentage of almonds damaged) using a non-parametric Spearman rank correlation test (2 tail; [24]), using the SPSS 13.0 software [24].

Of 3270 almonds recorded, 1036 (31.68\%) showed signs of damage due to the feeding action carried out by ring-necked parakeets (Fig. 1). The mean number of almonds available on trees was $46.54( \pm 18.27$, $\mathrm{n}=48)$. Among them, a mean number of $21.58( \pm 11.31)$ almonds showed signs of damage by ringnecked parakeet. Percentages of fruits damaged from the total of almonds available differed markedly among trees (from 2.78 to $90.69 \% ; \chi^{2}=57.13 ; p<0.001$ between extreme values). We showed a direct significant correlation between almonds available on trees and almonds damaged $\left(r_{s}=0.752, p<0.001\right.$, $\mathrm{n}=48$; Spearman rank correlation test, 2 tail, Fig. 2). We also observed a significant relationship between percentage of fruit damaged and distance (in $\mathrm{m}$ ) of almond trees to the orchard edge $\left(r_{\mathrm{s}}=0.445\right.$, $\mathrm{p}=0.002, \mathrm{n}=48$; Spearman rank correlation test, 2 tail).

Ring-necked parakeet seems to be the only non-native species locally impacting on this crop. Indeed, we have not observed individuals or signs of feeding attributable to the introduced monk parakeet, Myiopsitta monachus, known to be a species potentially damaging crops [23], despite the occasional presence of this species in the study site [20]; it is, however, more localized when compared to the ringnecked parakeet [25].

Previous research has highlighted that in Europe the ring-necked parakeet is an opportunistic granivorousfrugivorous species mainly foraging in parks and gardens, on ornamental non-native plants, and also exploiting human food sources [26-27]. For example, in Rome (Italy), parakeets eat Ulmus sp. samaras, Melia azedarach fruits and Quercus ilex acorns [14]. Our data add further evidence for our continent (the first for Southern Europe; see [16-17]) of an impact of this introduced bird on almond orchards.

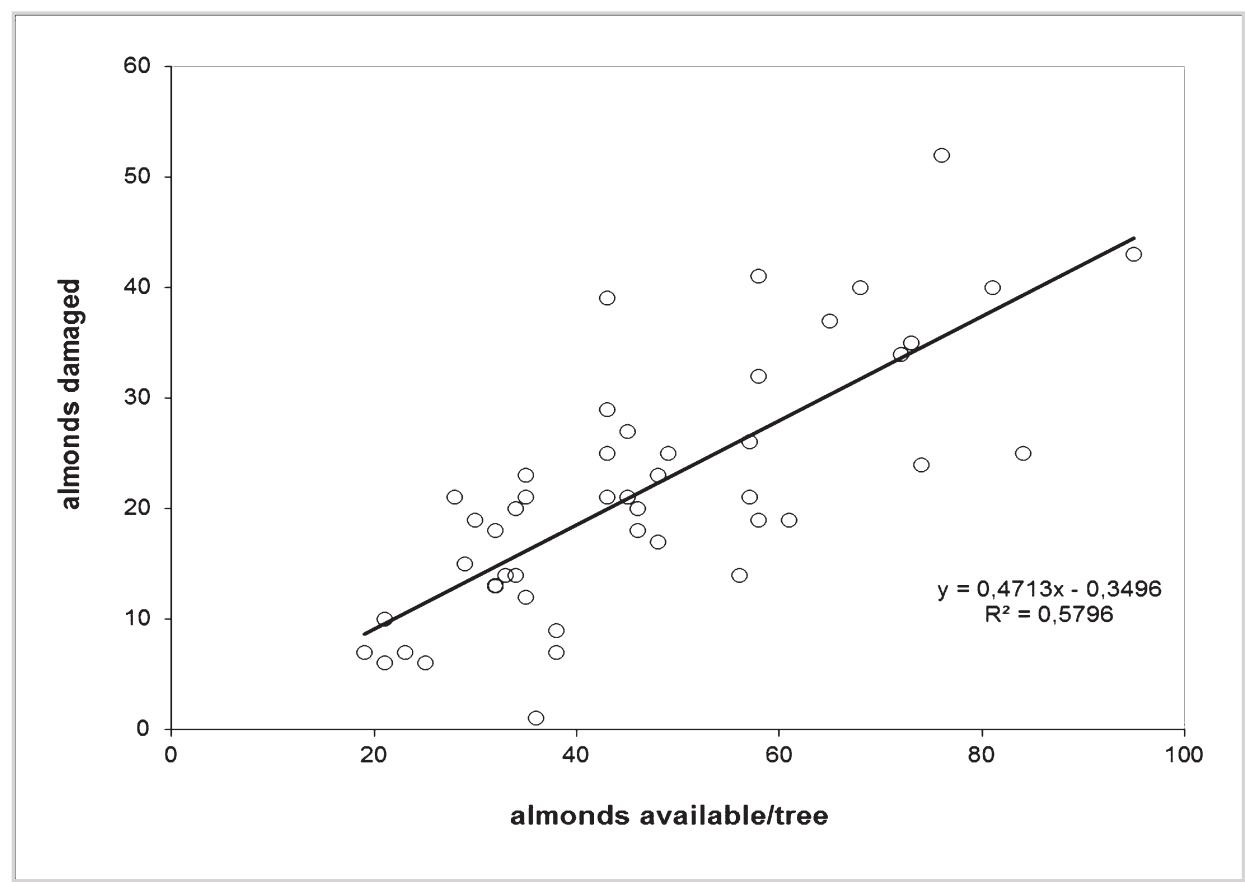

Fig. 2 - Relationship between available vs damaged almonds by ring-necked parakeet, Psittacula krameri. The equation of the better-fit line (linear) and coefficient of variation $\left(\mathrm{R}^{2}\right)$ have been reported. 
Almond cultivation is widely diffused in Mediterranean contexts [28]. Our evidence highlights that, where these parakeets occur, the level of damage could be significant (about 30\% of fruits damaged) and highly dependent (i) on fruit availability (significant correlation between almonds available and almonds damaged) and (ii) on the distance of trees from the orchard edge (significant correlation between percentage of almond damaged and tree distance from the edge). However, our data could be considered conservative: indeed, although we carried out this study immediately before the harvest period, damage could have further increased in subsequent days (until harvesting) since parakeets prefer progressively more mature fruits.

Actually, ring-necked parakeet is mainly localized in urbanized contexts [22] while almond cultivations are mainly distributed in rural landscapes [29]. In our case study, the impact observed might be due to a particular circumstance, i.e. the co-occurrence of an extensive experimental orchard located in a suburban landscape where ring-necked parakeet is very common [19-20]. Nevertheless, the progressive urbanization of rural landscapes (for central Italy: [30]) and the recent exponential expansion of ringnecked parakeet also in areas surrounding urban sites (for central Italy: [31]) make probable the potential impact of this species on orchards and other crops in the future.

In addition to ecological impacts on native species [21, 32-34], the economic impacts of ring-necked parakeet on agriculture have highlighted the need to expand effective management options [35]. Thus, it could be necessary to plan, even now, for the use of technical measures to reduce the impact of the ring-necked parakeet on these productive agro-ecosystems [9].

\section{Acknowledgments}

We wish to thank the staff of the experimental CREA-OFA Center (Consiglio per la Ricerca in Agricoltura e l'Analisi dell'Economia agraria) of Rome. Dr. Giulia Assogna provided us data on local abundance of parakeets. Alessandro Zocchi provided useful comments to the first draft of the manuscript and further revised the English style and language. The Editor-in-Chief (Isa Schőn) and three anonymous reviewers largely improved the first draft of the manuscript providing useful comments and suggestions.

\section{References}

1. Binimelis R., Born W., Monterroso I. \& RodrígueX-Labajos B. (2007). Socio-economic impact and assessment of biological invasions. In: NENTWIG W. (ed.) Biological invasions: 332 348. Springer, Berlin, New York.

2. Anderson A., Lindell C.A., MoXCey K.M., Siemer W.F., LinZ G.M., Curtis P.D., CARroll J.E., Burrows C.L., Boulanger J.R., Steensma K.M.M. \& Shwiff S.A. (2013). Bird damage to select fruit crops: The cost of damage and the benefits of control in five states. Crop Protection 52: 103-109. https://doi.org/10.1016/j.cropro.2013.05.019

3. Linz G.M., Bucher E.H., CANAvelli S.B., Rodriguez E. \& Avery M.L. (2015). Limitations of population suppression for protecting crops from bird depredation: A review. Crop Protection 76: 46-52. https://doi.org/10.1016/j.cropro.2015.06.005

4. Bruggers R.L., Rodriguez E. \& Zaccagnini M.E. (1998). Planning for bird pest problem resolution: a case study. International Biodeterioration \& Biodegradation 42: 173-184. https://doi.org/10.1016/S0964-8305(98)00046-8

5. StrubBe D., Shwartz A. \& Chiron F. (2011). Concerns regarding the scientific evidence informing impact risk assessment and management recommendations for invasive birds. Biological Conservation 144: 2112-2118. https://doi.org/10.1016/j.biocon.2011.05.001 
MENTIL L. et al., The impact of Psittacula krameri (Scopoli, 1769) on orchards

6. Strubbe D. \& Matthysen E. (2009). Establishment success of invasive ring-necked and monk parakeets in Europe. Journal of Biogeography 36: 2264-2278.

https://doi.org/10.1111/j.1365-2699.2009.02177.x

7. DHINDSA M.S. \& SAINI H.K. (1994). Agricultural ornithology: an Indian perspective. Journal of BioScience 19: 391-402. https://doi.org/10.1007/BF02703176

8. Ahmad S., KhAn H.A. \& JAVED M. (2012). An estimation of Rose-Ringed Parakeet (Psittacula krameri) depredations on Citrus, Guava and Mango in orchard fruit farm. International Journal of Agriculture \& Biology 14: 149-152.

9. KHAN H.A., JAVED M., TAHIR A. \& KANWAL M. (2013). Limiting the rose-ringed parakeet (Psittacula krameri) damage on guava (Psidium guajava) and mango (Mangifera indica) with an ultrasonic sound player in a farmland of Faislabad, Pakistan. African Journal of Agricultural Research 8: 6608-6614.

10. BABU R.S. \& MUthukrishnan T.S. (1987). Studies on the damage by Psittacula krameri (Scopoli) and Passer domesticus (Linnaeus) on certain crops. International Journal of Pest Management 33: 367-369. https://doi.org/10.1080/09670878709371185

11. SANDHU P.S. \& ChAKRAVARTHY S. (1982). Rose-ringed parakeet damage to almonds at Ludhiana in Punjab. Indian Journal of Agricultural Sciences 523:14-21.

12. SushiL K. (1994). Seed damage of tree Terminalia arjuna Bedd. by rose-ringed parakeet (Psittacula krameri) (Scopoli). Indian Journal of Forestry 17: 151-153.

13. Khan H.A., Beg M.A. \& Khan A.A. (2004). Breeding habitats of the Rose-Ringed Parakeet (Psittacula krameri) in the cultivations of Central Punjab. Pakistan Journal of Zoology 36, 133138.

14. Fraticelli F. (2014). The rose-ringed parakeet Psittacula krameri in a urban park: demographic trend, interspecific relationships and feeding preferences (Rome, central Italy). Avocetta 38: 23-28.

15. Menchetti M. \& Mori E. (2014). Worldwide impact of alien parrots (Aves Psittaciformes) on native biodiversity and environment: a review. Ethology Ecology \& Evolution 26: 172-194. https://doi.org/10.1080/03949370.2014.905981

16. Moran S. \& KeIDAR H. (1993). Checklist of vertebrate damage to agriculture in Israel. Crop Protection 12: 173-182. https://doi.org/10.1016/0261-2194(93)90105-R

17. Fletcher M. \& ASKew N. (2007). Review of the status, ecology and likely future spread of parakeets in England. Central Science Laboratory, York.

18. Kloen H., LOMMEN J.L., VAN DrongeLEN L. \& GuldeMOND J.A. (2014). Landbouwschade door halsbandparkieten. Schade-inventarisatie en risicoschatting. Publicatienummer CLM856, CLM Onderzoek en Advies, Culemborg.

19. SCARAFino C., TAFFon D. \& BAtTisti C. (2008). Comunità ornitiche in ambienti antropizzati (Parco dell'Appia antica, Roma): differenze ecologiche e stagionali. Rivista italiana di Ornitologia 78: $37-45$.

20. TAFFOn D., GiUCCA F. \& BATTISTI C. (2008). Atlante degli Uccelli nidificanti nel Parco regionale dell'Appia antica. Provincia di Roma, Assessorato alle politiche dell'agricoltura e dell'ambiente, Gangemi, Roma.

21. DodARo G. \& BATTISTI C. (2014). Rose-ringed parakeet (Psittacula krameri) and starling (Sturnus vulgaris) syntopics in a Mediterranean urban park: evidence for competition in nest-site selection? Belgian Journal of Zoology 144 (1): 5-14.

22. PÂrÂu L.G., Strubbe D., Mori E., Menchetti M., Ancillotto L., Kleunen A.V., White R.L., luna A., Hernandéz-Brito D., Le louarn M., Clergeau P., Albayrak T., Franz D., 
Braun M.P., Schroeder J. \& WinK M. (2016). Rose-ringed Parakeet Psittacula krameri populations and numbers in Europe: a complete overview. The Open Ornithology Journal 9: 1-13. https://doi.org/10.2174/1874453201609010001

23. Senar J.C., Domènech J., Arroyo L., Torre I. \& Gordo O. (2016). An evaluation of monk parakeet damage to crops in the metropolitan area of Barcelona. Animal Biodiversity and Conservation 39: 141-145.

24. Dyтнам C. (2011). Choosing and using statistics. A Biologist's Guide. Wiley and Blackwell, New York.

25. Di Santo M., Vignoli L., Battisti L. \& Bologna M.A. (2013). Feeding activity and space use of a naturalized population of Monk Parakeet, Myiopsitta monachus, in a Mediterranean urban area. Revue d'Écologie (Terre Vie) 67: 1-8.

26. Strubbe D. \& Matthysen E. (2010). A radiotelemetry study of habitat use by the exotic Ringnecked Parakeet Psittacula krameri in Belgium. Ibis 153: 180-184.

https://doi.org/10.1111/j.1474-919X.2010.01074.x

27. Clergeau P. \& Vergnes A. (2011). Bird feeders may sustain feral Rose-ringed parakeets Psittacula krameri in temperate Europe. Wildlife Biology 17: 248-252. https://doi.org/10.2981/09-092

28. Delplancke M., Alvarez N., Benoit L., Espindola A., Joly H.I., Neuenschwander S. \& ARRIGO N. (2013). Evolutionary history of almond tree domestication in the Mediterranean basin. Molecular Ecology 22: 1092-1104. https://doi.org/10.1111/mec.12129

29. Pinto-Correia T. \& VOS W. (2004). Multifunctionality in Mediterranean landscapes - past and future. In: Jongman R. (ed.) The new Dimension of the European Landscapes: 135-164. Wageningen FRONTIS Series, Springer, Dordrecht.

30. Romano B. \& Zullo F. (2014). Land urbanization in Central Italy: 50 years of evolution. Journal of Land Use Science 9: 143-164. https://doi.org/10.1080/1747423X.2012.754963

31. Brunelli M., Sarrocco S., Corbi F., Sorace A., Boano A., De Felici S., Guerrieri G., Meschini A. \& Roma S. (2011). Nuovo Atlante degli Uccelli Nidificanti nel Lazio. Edizioni ARP (Agenzia Regionale Parchi), Roma.

32. StrubBe D. \& Matthysen E. (2009). Experimental evidence for nest-site competition between invasive ring-necked parakeets (Psittacula krameri) and native nuthaches (Sitta europaea). Biological Conservation 142: 1588-1594. https://doi.org/10.1016/j.biocon.2009.02.026

33. Strubbe D., Matthysen E. \& Graham C.H. (2010). Assessing the potential impact of invasive ring-necked parakeets Psittacula krameri on native nuchaches Sitta europaea in Belgium. Journal of Applied Ecology 47: 549-557. https://doi.org/10.1111/j.1365-2664.2010.01808.x

34. Le louarn M., Couillens B., Deschamps-Cottin M. \& Clergeau P. (2016). Interference competition between an invasive parakeet and native bird species at feeding sites. Journal of Ethology 34: 291-298. https://doi.org/10.1007/s10164-016-0474-8

35. Lambert M.K., Massie G., Yoder C.A. \& Cowman D.P. (2010). An evaluation of Diazacon as a potential contraceptive in non-native rose-ringed parakeets. Journal of Wildlife Management 74: 573-581. https://doi.org/10.2193/2008-531

Manuscript received: 8 December 2017

Manuscript accepted: 16 July 2018

Published on: 1 August 2018

Branch editor: Diederik Strubbe 